\title{
Implementation Of The Local Minimum Wage In Malang City (A Case Study in Malang City 2014)
}

\author{
Dhea Candra Dewi ${ }^{1}$, Mardiyono ${ }^{2}$, M. Saleh Soeaidy ${ }^{3}$. \\ ${ }^{1}$ Magister Program, Faculty of Administrative Sciences, University of Brawijaya, Malang, Indonesia \\ ${ }^{2}$ Faculty of Administrative Sciences, University of Brawijaya, Malang, Indonesia \\ ${ }^{3}$ Faculty of Administrative Sciences, University of Brawijaya, Malang, Indonesia
}

\begin{abstract}
Wage system in a framework of how wages set and defined in order to improve the welfare of worker. The Indonesian government attempt to set a minimum wage in accordance with the eligibility standard of living. The study intend to analize the policy of Local Minimum Wage in Malang City in 2014, its implementation and constraining factors of those Local Minimum Wages. The research uses interactive model analysis as introduced by Miles and Hubermann [6] that consist of data collection, data reduction, data display, and conclusion.

Constraining factors seen at the respond given by relevant actors to the policy such as employer organizations, worker unions, wage councils, and local government. Firstly, company as employer organization does not use wage scale system as suggested by the policy. Secondly, lack of communication forum between company and worker union sounds very high. Thirdly, inability of small and big companies to pay minimum standard wages. Lastly, disagreement and different opinion about wage scale applied between local wage council, employer organization and workers union that often occurs in tripartite communication forum.
\end{abstract}

Keywords: Employers Organization, Local Minimum Wage, Local Wage Council, Policy Implementation, Tripartite Communication forum, Workers Union.

\section{INTRODUCTION}

Wages for workers are main component of their lives. Standard minimum wage paid by company in providing services for worker for their performance in a specified period. At the provincial level, the wage called as the Regional Minimum Wage (Upah Minimum Regional/UMR), this income based on national standards. After regional autonomy (Otoda) in 2000, this term became Local Minimum Wage (Upah Minimum Kota/UMK), this income based on city or regency standard.

Wage policy in Indonesia refers to standard of living fair for workers. The Act 13 of 2013 on Manpower [2] that the minimum wage should base on the needs of decent living needs (Kebutuhan Hidup Layak/KHL). Article one Paragraph 1 of the Regulation of the Minister of Manpower Number 1 of 1999 [7],

\footnotetext{
* Corresponding Address:

Dhea Candra Dewi

Email : dheacd@gmail.com

Address : Department of Magister Public Administrative Science, Faculty of Administrative Science, University of Brawijaya.
}

defines the minimum wage as "the lowest monthly wage covering basic salary and fixed allowances..." As a reward from employers to workers, wages are given in the form of cash should be determined on the basis of an agreement or legislation and are paid on the basis employment agreement between the employer and the worker, including benefits, both for the workers themselves and their families.

The minimum wage is a basic salary and allowances are set regionally, sectorally and sub-sectorally. The upcoming regulation of Minister, also establish sectoral minimum wage at the provincial level that should be at least five percent higher than the standard minimum wage for the province. Similarly, sectoral minimum wage at the regency/city should be five percent higher than the standard minimum wage regency/city.

Discussion about workers, we actually concern to human resources and their complexity. Workers are the only assets of the company who support in achieving the goal of company. Workers as human resources assets are different with others assets, because 
workers have rationality, feelings, and behavior. As long as workers managed well, they will be able to contribute for companies actively.

Discussion about minimum wage is not limited to the formulation and determination of the value of wages. Another issue that increasingly becomes a public attention on how the implementation of the minimum wages itself. Today, the implementation minimum wage in various places within the provincial, regional and regency/city increasingly reap many problems. The problems that arise on average, the value of wages specified in the formulation process was not in accordance with the approved wage. That condition considered as normal things, when a decision of local minimum wage cannot satisfy every element in policymaking. The workers feel their demands had not met yet. Employers also find it hard to raise the value of the wages they have to pay. Both sides would have their own reasons.

Malang City is one of the cities whose economies supported by industrial activity, which contributes to the formation of its gross domestic product reached $33.06 \%$. Number of employees groups industrial activities. Groups of small and household industry is an industry with a power of less than 10 people, the group is a company with the industry being labor and the 20-99 is a large industrial group with a workforce of the company is equal to or more than 100 peoples. Statistic area Malang on profile Malang City, 2013 [10].

Policy or programs made by the government including the implementation of local minimum wage, as one form of policy or program to prosperity. Later, in the policy implementation process of partiality will arise between the interests of society, especially the interests of workers and employers. The policy expected to implement properly in order to create well-being in society as part of the success of the policy.

As explain before, researcher found and describe indication that was not optimal in implementing the local minimum wage policy. Therefore, researcher encourage to conduct research on the implementation of the minimum wage policy is conducted in the Malang City.

\section{RESEARCH METHOD}

Beside on the description, the researchers use qualitative research. Descriptive research with qualitative approach chosen by researcher because considered especially appropriate for this research.

\section{Data Collecting Process}

Data collection process is the strategic step in the study, because the main objective of the research is to get the data. The data collection process use in the research by Miles and Huberman [6] as interactive model analysis:

1. Observation method

2. Interview method

3. Documentation method

\section{RESEARCH FINDINGS}

1. The Implementation of Local Minimum Wage Policy in Malang City 2014

The East Java Government Regulation No. 78 Year 2013 on Local Minimum Wage in East Java in 2014 [4] states that local minimum wage in Malang City 2014 is 1.587 million rupiahs. This decision applied based on the determination of the East Java Governor and the agreement by local wage councils in Malang City. Wage Council in accordance with the Presidential decision of the Republic of Indonesia No. 107 of 2004 on Wage Council [9] is a non-structural organization that is tripartite. A Council which set the value of local minimum wage is called the local wage council. The tasks of local wage council are giving advice and opinions for the Mayor to set local minimum wage policy. In addition, they also have to apply the remuneration system at the municipal level.

The implementation of local minimum wage policy in Malang City 2014 is a dynamics process. Started from formulating policy, implementing, and resulting. According to Lester and Steward cited by Agustino [3], that the policy implementation as a process and outcome. The process and the achievement of the result can measure the success of a policy implementation, which is whether the goal can achieve.

Implementing local minimum wage policy in Malang City 2014 consists of several policies that accompany. The supporting policies are: First, East Java Government Regulation 78 of 2013 is on Local Minimum Wage in East Java [4]. This regulation as a formal form in the establishment and implementation of the 
Minimum Wage City. Second, Kepmenakertrans 231/men/2003 is about Suspension Procedures for Implementing Minimum Wage. This regulation as procedures in suspending of paying and protection wages. Third, the Act 13 of 2003 is about Manpower [2]. This regulation as sanctions and supervision by the Manpower and Transmigration Department Malang City to the actors involved in the implementation of the minimum wage.

Figure 1 Main Process Formal Form of Implementing Local Minimum Wage Policy in Malang City 2014

Rule setting and implementation of minimum wage

Rule of Implementation minimum wage protection

\section{Rules of} supervision and sanctions

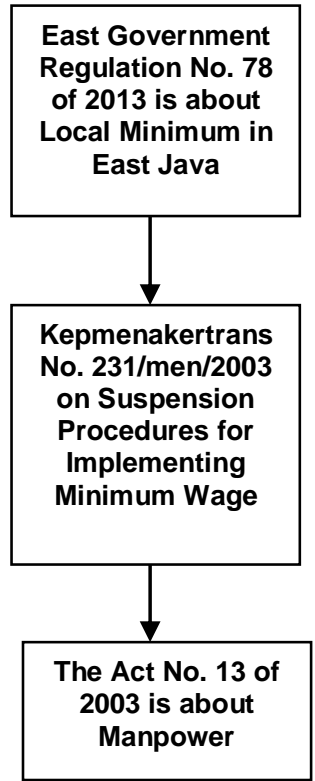

Source: processed by the researcher

a) The Bureaucratic Structure of Local Minimum Wage Policy in Malang City 2014

Local minimum wage policy begins with the establishment of local wage councils. According to the Presidential Decree 107 of 2004 on Wage Council [9], understanding Wage Council is a non-structural organization that is tripartite. This institution consists of representatives from trade unions, employers' organizations, and government. The function of local wage councils is to provide advice and consideration for nomination to the Mayor and Minimum Wages application of the remuneration system in the local stage. The composition of local wage council consists of:

1. chairman who also becomes a member of the government element;

2. the deputy chairman who also becomes member of the college element;
3. the secretary who doubles as a member of a government that represents the working units which has responsibility for the field of industrial relation;

4. manpower and Transmigration Department Malang City,

5. members that are include in worker unions and employers' organizations.

In the bureaucratic structure of local wage council, consists of several sections according to each tasks. Part of its structure consists of a director, coordinator, deputy coordinator, chairperson, vice chairperson, secretary, and several members. Members in local wage council in Malang City consist of government and employer elements represented by three employers' organizations, as well as the elements of workers represented by three unions. With local wage council, there are elements of the entrepreneur and worker elements, and then it makes local wage council also has a responsibility in the implementation of local minimum wage policy in Malang City 2014.

Thereby it can conclude that the bureaucracy structure as a formal mechanism. Bureaucratic structure also shows a framework among the actors in carrying out their affairs. Policy Implementation of local minimum wage policy in Malang City 2014 done by the government supervision. Therefore, the local wage council expected to monitor implementation of local minimum wage policy in Malang City 2014.

\section{b) Resources of Local Minimum Wage Policy in Malang City 2014}

The resources become main variables after the bureaucratic structure in policy implementation. Resources classify as human resources, information resources, financial resources, and so on. In the implementation of local minimum wage policy in Malang City 2014, human resources who implement the policy are the employer organization. Human resources in the organizations of employers have the obligation to pay full wages to the workers in the company of each worker in the company.

Human resources in the implementation of the local minimum wage policy in Malang City 2014 begin with membership of local wage council. Human resources as a media of 
delivery of information that disseminated. The second source is information sources. Information source concern to deliver information about local wage minimum value from employer to they worker. Furthermore, the role of information source is delivering the information from head of the employers' organization to workers.

According to Grindle quoted by Agustino [3] the success of the policy strongly influenced by the policy content on of component is the variable commitment of human resources. It also occurs in the implementation of local minimum wage policy in Malang City 2014. When the human resources in local wage council in Malang City are not in one consensus, then the implementation of local minimum wage policy in Malang City 2014 will not realized. It can make problem in remuneration system applied properly.

Another problem besides the inability of employers' organizations in the suspension is less of human resources in the government for monitoring the implementation of local minimum wage in Malang City 2014. Human Resources governments are limited in some people, thus could not control all of companies. In addition, besides government resource, financial resources has also become one of the obstacles in the process of monitoring the implementation of local minimum wage policy in Malang City 2014 by elements of government oversight plays a fundamental role in the event of a discrepancy implementation of local minimum wage policy in Malang City 2014. The role of government can applied by giving a warning, more insight further, and sanctions within the organization and its members who have failed to pay in accordance with the existing policy.

\section{c) Communication of Local Minimum Wage Policy in Malang City 2014}

In order to implement a minimum wage policy, need for communication between the actors. Actor implementing the minimum wage policy consists of the employers as the owner of the company and the workers as implementers. Communication is created within the framework of the implementation of the minimum wage policy can form of working relationship between the two there is a wage payment transactions.

Communication aspects in policy implementation formed between the tripartite.
Tripartite is a cooperation agencies form of communication, consultation, and dialogue between three actors. The actors consist of: government, employers' organizations, and worker unions. Tripartite communication held by the government on behalf of the Department of Manpower and Transmigration Malang City with employers' organizations and worker unions while it is still rarely done. The intensity of meeting between the three just happens in a meeting four times a year. In fact, according the agenda of the meeting that there should be held a forum of communication is conducted at least once a month. This influenced by the presence of a budget that owned by the department.

Unlike the situation in a tripartite forum for communication, internal forums employers often hold even more communication forum. So also with the internal communication forum that unions tend to have many agendas among they members. Unfortunately, internal meetings among unions had not done in the forum regularly. Therefore, the communication forum held by the employer's organizations, employers' organizations very rarely open forum for communication to other unions. It is because of the difference in interest between the two parties.

Communication in implementation of local minimum wage policy in Malang City 2014 consist of employers' organizations, worker unions, and the government has only occurred in the forum local wage council. Forums that bring together the three actors, in which to discuss issues about wage system. The rest, for the meeting of the three forums, are still rare. Supposed to establish cooperation and harmonious relations, especially for unions and company organizations, it is necessary to intensity sufficient communication. It used to determine the problems that occurred and will look for solutions to these problems, including problems related to payment of the minimum wage are still not appropriate.

According to Winarno [12] the factors that encourage the vagueness of information in public policy implementation is usually because of the complexity of the policy, the lack of consensus on public policy objectiveness the existence of problems in starting a new policy and the tendency to avoid accountability policy.

Policy implementation process consists of various actors that involved from top management to the lower level of bureaucracy. 
Effective communication requires clear communication with the organizing process to earlier stages. If there is any contradiction of the executor, the policy will be ignored and distorted. For what, Winarno [12] concluded more layers or executive actors involves in policy implementation, the more likely facing barriers and distortions.

\section{d) Disposition of Local Minimum Wage Policy in Malang City 2014}

Disposition in the implementation of local minimum wage policy in Malang City 2014 supporting the important thing is the attitude of the implementers of policy implementation. That is, the union is willing to take a stand in order to implement the policy; it is highly dependent on the extent of the authority of the union itself. Therefore, the attitude taken by the organization willing workers should regularly carry out the minimum wage policy. According to Abdul Wahab [1] explain that the character and disposition are characteristic Possessed by the implementers, such as commitment, honestly, democratic nature. If the implementer has a good disposition, the policy implementation can run well as what policy Desired by policy makers.

From the research that has conducted in order to see the attitude of the policy implementer, found a few things that still need to explain. The policy implementer is the employers who pay wages to the workers. Wages are set in the minimum wage policy while still a minimum wage as a safety net and given to the workers who are still under the age of 1-year workings. Further, the employer should pay wages in accordance with the scale of work to workers in their company. Employers and company policies so far there is still limited to paying the wages of minimum wage workers when working scale is called long enough to work. An understanding of this is necessary to make implementation of local minimum wage in Malang City 2014 well done.

Under the regulations, the minimum wage is the wage applicable to new workers entering or working less than one year. In practice, many companies set the minimum wage as a standard rule, where all workers receive a wage for minimum wage. For workers, this is an issue because workers who have worked longtime treated the same as new workers enter. So that the workers felt that, the company did not assess the experience. Workers in some companies consider that the company set the minimum wage as a remuneration standard. Workers see, that the company is actually able to provide a higher level of wages, but because there is a minimum wage policy only then set wages around the minimum wage.

According to the concept of the reality of the implementation of the policy, which states that, the core of the implementation of the policy influenced by a number of contexts, consists of social conditions, economic, technology, and political by Howlet and Ramesh [5]. So that happened in the implementation of local minimum wage policy in social conditions that influence the implementation of local minimum wage policy in Malang City 2014 social unrest form of union wage policy that responds to the presence of the. Some of them agreed with the outcome predetermined local minimum wage policy, but there are several other unions have not agreed with the outcomes determined. Other contexts, which are affect implementation of local minimum wage policy that economic conditions. Economic conditions of the workers are expected to achieve a better level after these minimum wage regulations. Therefore, with the political conditions that exists in the implementation of the minimum wage policy. Difference of interests between employers and union organizations are so clearly visible. On the other hand of the employers' organization wants a minimum wage value based on the minimum wage standards obtained from the results of the market survey, while the union wants wage really enough for the needs of daily living. 
Figure 2 Stages the implementation process of local minimum wage in Malang City 2014

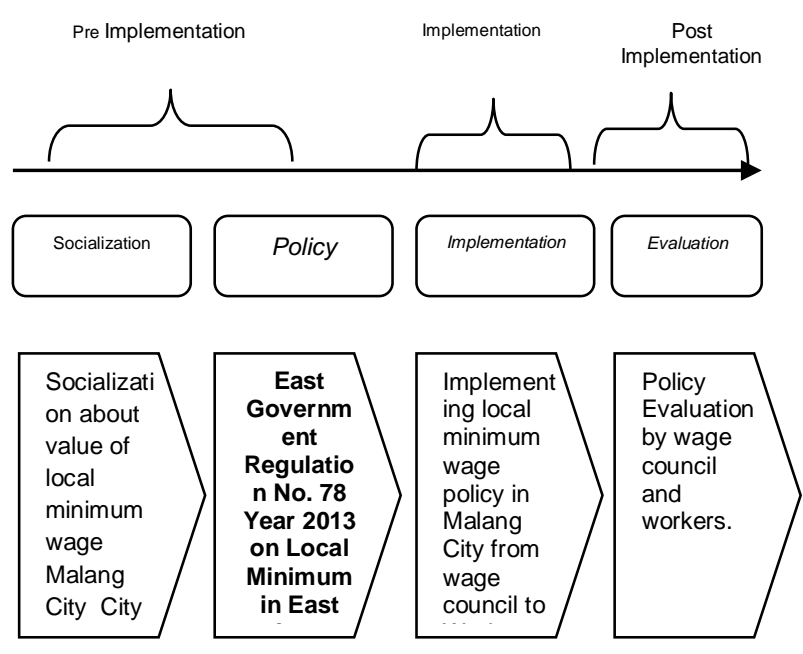

Source: Processed by researches

The implementation of local minimum wage policy in Malang City 2014 also seen through the stages of the implementation process as according to Nugroho [8]. The stages of the policy implementation process divided into three stages that is the preimplementation, implementation and post implementation.

In the implementation of local minimum wage policy in Malang City 2014, the preimplementation stages described by a process of socialization by wage council. Socialization is done to the company and worker united. Socialization done usually one month after the decree of the governor of the value of the minimum wage takes effect. Then, one month after the socialization, the company implements the value of minimum wage. Through the pre-implementation process is also the policy of the present minimum wage

The second stage is about payment of local minimum wage policy in Malang City from company to Workers. In the implementation process, each company has obliged to pay the value of wage as determined to workers in the company concerned. Each worker also required to know the legal basic in the payment of the minimum wage regulations. In addition to knowing the basic law, workers are also required to find out how much the value of the minimum wage paid to them. This process can be done knowing assistance by the union to they members.
Finally, the last stage is about evaluation of the policy. Evaluation of minimum wage policy carried out by wage council, which had formed the wage. Policy evaluation done based on recommendations made from the evaluation result of Manpower and Transmigration Department in Malang City. Implementing evaluation of local minimum wage policy done by Manpower and Transmigration Department in Malang City. Point of minimum wage policy evaluation conducted in observance of the company paying the minimum wage to workers. If there are companies that cannot afford to pay wages, can be suspended efforts by companies to governments in order suspension of payment of the minimum wage in accordance with the rules Kepmenakertrans No.231/men/ 2003 on Suspension Procedures For Implementation of the Minimum Wage.

\section{Constraining Factors in implementing Local Minimum Wage in Malang City 2014}

According to Sunggono [11] many factors led to a policy cannot run as expected. The concept of multiple factors that become constraining factors such as content policies, support, potential distribution, and the information conveyed. Policy implementation may fail because the contents of the policy. Contents policies lack detail, what the objectives are not clear enough policy, policy programs are too general.

One of constraining factors in implementing local minimum wage policy looked by the support given to implementing the policy. Support for this policy such as how to respond to an existing policy. In local minimum wage policy implementation, the support afforded views of how the actors respond to the implementation of the local minimum wage policy Malang City 2014. Actors who related directly in the implementation of the minimum wage consist of employer's organizations, worker unions, local wage council, and local governments.

\section{a) Perspective of Labor}

From the perspective of worker unions in Malang City, not all of the individual members get paid wages in accordance with the remuneration policy. Typically, union members who work at companies with small and medium scale that cannot receive wages in accordance with prescribed. This is due to the inability of the company to pay, because the company's 
revenue is not enough. Unfortunately, smallscale enterprises that cannot afford to pay wages according to the rules, do not immediately apply to the governor on the existing wage rate. Companies prefer to pay modest wages to workers. Similarly, the workers, they prefer to continue to receive however much income paid by the company to them.

Under the regulations, the minimum wage is the wage applicable to new workers entering or working less than one year. In practice, many companies set the minimum wage as a standard rule, where all workers receive a wage for minimum wage. The company argued that because of rise in the minimum wage too fast compared to regular wage increases. For workers, this is an issue because workers who have work long treated the same as new workers enter. So that the workers felt that, the company did not assess the experience.

Workers in some companies consider that the company set the minimum wage as a wage standard. Workers consider that the company is actually able to provide a higher level of wages, but because there is a minimum wage policy only then set wages around the minimum wage. When the company is progressing and increasing profit levels, permanent workers paid around minimum wage. So that workers feel that, the minimum wage policy would be a barrier for workers to get a fairer wage levels, although in certain cases such as large companies have not felt this kind of policy is enough to help the workers.

Another constraint suffered by unions and their members that the lack of a forum for communication between organizations formed corporations and unions. Unions always felt the need to coordinate the organization of employers in any employment policy there. This way, any problems that exist among worker union members who deal directly with the entrepreneurs can be immediately resolved.

\section{b) Perspective of Corporate Managers}

Decree of the President of the Republic of Indonesia 107 of 2004 on Wage Council [9], explains that employers who appointed by the Chamber of Commerce and Industry to address the issue of employment. Apindo (Indonesian Employers Association) is one of the organizations in Malang City. The employers' organization is also a member in the Wage
Council. The employers' organizations whose members are about 80 companies, the implementation of local minimum wage policy in Malang City 2014 assume no significant obstacles. Most of the member companies of Apindo have conducted according to the amount of the agreed wage rate in the wage boards. It concludes that Apindo is an organization of companies related in large scale.

Another obstacle, that possibly happened on a large-scale company and small-scale company in the implementation local minimum wage policy in Malang City 2014. Large-scale companies will be able to pay wages in accordance with the collective agreement, but there are still some small companies still do not pay it and do not perform a process suspension. Scale companies also affect the ability of the company in the application of the wage rate. In general, large companies can provide higher wages than the minimum wages than smaller firms can.

As described in the regulations, that the employers' organization is the representative of the company. The company is implementers of local minimum wage policy. If there are some companies who are not able to pay wages in accordance with the minimum standards, the company should immediately file a deferment of payment of minimum wages to the governor ten days after the determination of local minimum wage policy. The suspension is expected to resolve the problem as it exists at the workers' wages acceptance in accordance with the minimum wage standards. Because if the company is unable to pay wages when appropriate standards, then the company will be sanctioned by the Department of Manpower and Transmigration has a duty as a supervisory course of implementation wage policy.

\section{c) Perspective of Local Government Consideration}

The local government is responsible of the wage system in this case is the Department of Manpower and Transmigration Malang City always try as quickly as possible and as clearly as possible in providing socialization on the amount of the minimum wage that must be paid by the company to the workers. Constraints faced by local government lack of openness, which is a small or medium-scale company that have not been able to pay wages 
in accordance with the minimum value, but does not give information to the suspension of local government.

Local governments also assess the policy of the minimum wage system, which considered as the only company wage policy that must be implemented in the employment relationship. Yet in addition, the problem of wages is also not free from the wage scale, namely the payment of wages to workers that based on length of service and skill possessed. The minimum wage policy is actually only used as a safety net for new workers in the company that still has a working time of under one year. In addressing issues of the wage scale, the local government considers that wage scale is the company's obligation to make and implement, because the wage scale is in organizing its private policy.

According to the Ministry of Manpower and Transmigration No: Kep. 49/MEN/2004 on Terms and Structure of Wage Scale behold wage structure is the arrangement of the wage rate from lowest to highest or from highest to lowest. Meanwhile, according to the same ministerial decision, the wage scale is the range of the nominal value of wages for each occupation group. With the implementation of the regulations governing the structure and scale of wages, the company should no longer be uniform all workers who work on a one-year period using the minimum wage policy. Payment of the wages they receive should be above the prescribed minimum wage.

\section{d) Perspective of Wage Council}

Local wage council is spearheading the city minimum wage policy formulation and implementation of the minimum wage policy of the city. At the time of the formulation to the implementation of a policy, there is often disagreement between employers and employees in relation to the total amount of the minimum wage to be paid. In the forum Wage Council, workers always request that the total value of the minimum wage increase along with his complex needs of everyday life. In addition, the company chose to find a number value to a minimum wage, according to the components of a decent life but budgeted with a minimum value. This is related to the urgent needs of the company in addition to the payment of wages.
A constraint that faced by local wage councils in the implementation of local minimum wage policy in Malang City 2014 is a difference of opinion that often occurs in the tripartite forum held communications. For instance, forums of living needs that determine value and different opinion. Dissent is indeed very difficult to find a similar deal. Typically, councils choose the middle ground by holding a joint survey in order to determine the value of local minimum wage. Likewise, when the implementation process of local minimum wage policy in Malang City 2014, the Wage Council is not necessarily hold in the Industrial Relations Court to the employers who violate minimum wage laws, but still provide guidance and tolerance limits for employers' organizations. This is done also in order to protect the workers in order to avoid termination of employment (PHK) which is likely to affect adversely the workers.

\section{CONCLUSION AND RECOMMEDATION}

\section{a. Conclusion}

1. Regulation East Java Governor No. 78 of 2013 on Local Minimum Wage in East Java 2014 [4], mentioned that value of local minimum wage in Malang City 2014 is 1.587 million rupiah. This decision based on the determination East Java Governor and above the agreement local wage council in Malang City. The process of implementation local minimum wage in Malang City 2014 has not done well, some companies still that do not pay the minimum wage in accordance with the regulatory standards of worker.

2. Constraining factors in implementation of local minimum wage policy in Malang City 2014 can be seen from the support the policy. Support for this policy is how to respond existing policy. Any differences among company and workers interest in the implementing of wage. Company always wants a minimum wage as minimum; beside that, workers always require a high standard of wage.

\section{b. Recommendation}

Based on the conclusions statement that has written, the researcher gave the following suggestions, that:

1. Local Minimum wage policy in Malang City 2014 is a step in the conduct of government services to the public, on behalf of the 
elements of public workers in order to protect the wages they receive. Successful implementation of local minimum wage policy in Malang City 2014 done with the help from government in monitoring and fostering more routine and depth to the employers' organizations, so companies who are members pay obligations in local minimum wage policy according to the workers based on liability.

2. The support employers to pay a minimum wage according to standard, support workers receiving minimum wage in accordance with the regulation. Government can support this policy by monitoring process implementation of the minimum wage to the employer as a core actor implementing policy. In anticipation of the problem caused by the difference interest among company and worker each year, depends on the extent to which role of workers united in the company. They must give a explanation, socialization, and continuously to members whenever there are wage increases, both from government and company.

\section{ACKNOWLEDGEMENTS}

In finishing this journal, the writer really gives his regards and thanks for people who has given guidance and help, they are:

1. Dr. Mardiyono, MPA., the first supervisor, who has given his best guidance to write a quality content of the thesis.

2. Dr. M.Saleh Soeaidy, MA., the second supervisor, who has given his help to show the best way to research.

3. Drs. Kasiyadi, MM as Head of Division Industrial Relationship, Manpower and Transmigration Department Malang City.

4. Hari Effendi, as Chairman of Serikat Buruh Seluruh Indonesia, Union Federation in Malang City.

5. Edi Sulistyo, as a member of Asosiasi Pengusaha Indonesia, branch Malang City.

6. Sunari, SE, as a vice of Serikat Persatuan Pekerja Indonesia, branch Malang City.

7. Faizin, as a Chairman of Solidaritas Persatuan Buruh Indonesia, branch Malang City.

\section{BIBLIOGRAPHY}

[1] Abdul Wahab, Solichin. 2008. Pengantar Analisis Kebijakan Publik. Malang City: UMM Press.

[2] Act No. 13 the Year 2013 on Manpower

[3] Agustino, Leo. S.Sos. 2008. Dasar-Dasar Kebijakan Publik. Bandung: CV.ALFABETA.

[4] East Java Government Regulation No. 78 Year 2013 on Local Minimum Wage in East Java 2014.

[5] Howlett, Michael. M. Ramesh. 1995. Studying Public Policy: Policy Cycles and Policy Susbsystems. Oxford University Press, Oxford.

[6] Miles, Matthew B and Michael Huberman. 1994. Qualitative Data Analysis Second Edition. London: SAGE Publications.

[7] Minister of Manpower No. 1/MEN/1999 on Minimum Wage.

[8] Nugroho, Riant D. 2006. Kebijakan Publik Untuk Negara-Negara Berkembang: Model-model perumusan, Implementasi dan Evaluasi. Jakarta: PT Elex Media Komputindo.

[9] Presidential Decision No.107 Year 2004 on Wage Council of The Republic of Indonesia.

[10] Profile Malang City 2013. Kota Malang Dalam Angka. Malang: Badan Pusat Statistik.

[11] Sunggono, Bambang. 1994. Hukum dan Kebijaksanaan Publik. Jakarta: Sinar Grafika.

[12] Winarno, Budi. 2002. Kebijakan dan Proses Kebijakan Publik. Yogyakarta: Media Pressindo. 